\title{
The Soft Power of Development: Aid and Assistance as Public Diplomacy Activities
}

\author{
Dr. Colin Alexander - colin.alexander@ntu.ac.uk \\ Lecturer in Political Communications, Nottingham Trent University \\ NOT TO BE QUOTED IN THIS FORMAT: see published version
}

Published version is available at https://doi.org/10.1007/978-981-10-7035-8_74-1

Alexander C. (2018) The Soft Power of Development: Aid and Assistance as Public Diplomacy

Activities. In: Servaes J. (eds) Handbook of Communication for Development and Social Change.

Springer, Singapore

\section{Abstract}

Following a political communications framework can provide useful critical understanding of the international philanthropic industries beyond the more traditional approaches of political economy, anthropology and postcolonial studies. To this end, this chapter frames foreign aid and development assistance through theories of soft power, arguing that these activities are acts of public diplomacy and thereby conducive to the source government's power accumulation motive. This is open to some contest across the literature as research framed under international political economy or social anthropology often assumes that international power redistribution is the primary motive. Analysis of these programmes under the soft power framework allows for the discussion of the multitude of audiences that the activities engage with beyond the direct recipients of assistance as part of the power accumulation precedent. The chapter will hereby discuss the role of morality and compassion within the policy-making process, which leads to the question of whether we should really be considering whether most aid and development is in fact meant to work rather than the more popular query of why so much of it does not work.

\section{Introduction}

The propaganda that surrounds foreign aid describes its altruistic and compassionate motives. However, far from any empathetic or developmental intent, foreign aid is primarily motivated by the consolidation of the power status of the source as usurper and the recipient as usurped. To this end, an understanding of foreign aid and development assistance through the prism of soft power - the term coined by Joseph Nye (see 2004) at the end of the Cold War to describe when power in international politics is achieved through attraction rather than coercion or persuasion - is useful to wider understanding of the grand purpose of these industries. At the crux of this paper then is an attempt to provide an explanation for why so-called foreign aid and development assistance does not work. If, by 'work', it is meant that programmes facilitated by international governmental actors reduce extreme poverty, relieve destitution, improve educational attainment, deliver vital skills training, while at the same time respecting aspects of culture, human movement and the environment, then foreign aid and development assistance has been a catastrophic failure as it has made no contribution to a more egalitarian and fairer world that purports to be its motivation. To this end, the question may be better phrased as 'is foreign aid meant to work?' because its perpetuation seems to be based on it satisfying alternative power ambitions to those that it claims. 
The nineteenth century German philosopher Arthur Schopenhauer (1995) argued that compassion should be the only motivation if an action is to be considered as philanthropy. As such, the foreign aid industries communicate from a disingenuous platform as they primarily exist to fulfil the power ambitions of the source or self-styled 'donor' state. We understand this because, as Arturo Escobar (1995: 21) explains in jest, the poverty of certain parts of the world appears to have been 'discovered' after World War II when the narrative surrounding the planet's poorest people became one of deliverance from their destitution. It was as though the former colonial exploiters had suddenly discovered their moral compass. To this end, the post-war growth of the foreign aid industries was part of attempts to ensure political and economic continuity in the postcolonial era and was only interested in poverty alleviation to the extent that it benefited the major powers as they continued their exploitation of these territories.

The key argument made by this chapter is that communications analysis of foreign aid can provide an alternative framework to those more commonly used from political economy, anthropology or postcolonial studies, and that this may assist with the repositioning of wider questions concerning development studies generally. As such, this chapter will discuss foreign aid as acts of public diplomacy: a distinct political communications terminology referring to attempts made by governments to engage with foreign publics as befitting strategic goals. The intent of these activities is normally the generation soft power for, or the bestowment of attractiveness upon, the source of these communications. To be clear therefore, the mechanisms of foreign aid tacitly communicate messages of virtuosity regarding the source to numerous domestic and international audiences. Thus, while public diplomacy is predominantly considered to have international priorities, it can also be linked to governmental priorities concerning its domestic public. Beyond this, foreign aid under a public diplomacy framework also forms part of governmental attempts to demonstrate congruence with prevailing international ideological norms and deontological guidelines regarding the responsible behaviour of wealth states. In today's case this involves the propagation that supposed international philanthropy can be an adequate counterweight to the acceleration in global inequality that has been the result of neoliberalism. However, much like other activities that are propagated as philanthropy under this ideology, foreign aid and development assistance have little intent to offer social justice and should always be considered part of the exploitation rather than any offset against it.

Herein lies one of the fundamental limitations of democracy: that it cannot deliver meaningful change, partly because group consensus almost always produces an egotistical outcome (see Niebuhr, 1932). For example, democracy is ill-equipped to reverse or stifle the effects of climate change because its institutions refuse to enforce the necessary restrictions on the consumptions of the electorate lest the leadership become unpopular. Democracy involves the art of dream selling and the limitation of toil, and this rarely involves a utopia of human reintegration with the natural world. Thus, political leaders who fail to adequately nourish the collective ego of the electorate normally have short-lived political careers. Consequently, governments maintain the fiction that foreign aid is motivated by philanthropic rather than strategic and economic interests because this assists with the nourishment of a domestic collective ego that the country and its citizens make a positive contribution to the planet beyond consumption of its resources. It then gains uncritical support from many echelons of the public who misguidedly support foreign aid as a form of state charity because this feeds the individual ego's desire to perceive oneself as virtuous within the prevailing ideology. However, this is a subconscious self-deception that has been incentivised by ideological hoaxing seeking to create feelings of worthiness within the consumer that lead to optimal consumption. As such, worthiness is normally maintained in one of two ways under these conditions: either through forms of collective or individual voluntary penance that are paid at the 
point of transaction to permit a guiltfree continuation of a supposedly virtuous existence of inconsequential behaviour; or in the form of foreign aid, wherein a government claims that taxation monies are assisting the world's poor who suffer misfortune rather than the effects of an organised system of denial. These propagandas essentially seek to maintain capitalism's profit-making imperative by detaching the consumer experience from the reality of its implications on the world's poor, and indeed the environment, and keeps hidden that a reduction in consumption would assist both the balance of humans with the planetary ecosystem, while also improving the relations of humans with other humans.

Much of the philanthropic industries then exist in a doublespeak world reminiscent of George Orwell's classic dystopian novel 1984. Orwell (1949) provides the adage of the Ministry of Peace, which makes war; the Ministry of Truth, which lies; the Ministry of Love, which tortures; and the Ministry of Plenty, which starves. Orwell argued that these acts of doublespeak are essentially attempts by the state to misconstrue the consciousness of the people. To this end, much like our Ministries of Defence are more concerned with outward aggression, it can be argued that the use of words like 'aid', 'development', 'assistance' and the notion of 'donors' and 'donations' are Orwellianstyle propaganda. The industry communicates in a philanthropic language using terms like 'support', 'dignity', 'compassion', 'capacity' and the 'alleviation of hardship'. However, perhaps rather than being called the United States Agency for International Development (USAID) or the British Department for International Development (DfID) it would be more accurate to call them Agencies or Departments for International Diminution.

The remainder of this chapter has been split into three subsections. The first provides a wider academic discussion of the compatibility of morality with the foreign policy process. This is important because it helps to frame the extent to which foreign aid misrepresents itself as an act of state philanthropy. The chapter will then provide a specific discussion of soft power and public diplomacy within the context of development studies. Finally, the chapter will provide some concluding remarks concerning foreign aid and development and wider positions regarding prevailing ideology and the propaganda that justifies itself.

\section{Morality and Foreign Policy}

The eighteenth-century philosopher Jean Jacques Rousseau wrote in The Social Contract that,

Since no man has a natural authority over his fellow, and force creates no right, we must conclude that conventions form the basis of all legitimate authority among men. (Rousseau, 1993: 185)

These 'conventions' may pose as moral authority. However, they are upheld for the primary purpose of the maintenance of power structures by those who propagate their value. Transferred to international politics then, it can be argued that no state has entitlement to its international power. As a result, states strategically communicate with domestic and international audiences in an attempt at orchestrating value judgments about themselves that serve their power ambitions. To this end, public diplomacy activities form part of the alibi that states propagate in an attempt at convincing others of their power ambitions despite a lack of legal or moral entitlement therewith. Indeed, if power was guaranteed then there would be little need for these strategic communications. As such, public diplomacy is often the ground on which governments propagate an ethical compliance of sorts with prevailing international norms. This is notwithstanding the 
authenticity of these communications as it is power rather than compliance that is their primary objective.

On the role of morality in foreign policy then, Nicholas Spykman has argued that,

The statesman who conducts foreign policy can concern himself with values of justice, fairness, and tolerance only to the extent that they contribute to or do not interfere with the power objective. They can be used instrumentally as moral justification for the power quest, but they must be discarded the moment their application brings weakness. The search for power is not made for the achievement of moral values; moral values are used to facilitate the attainment of power. (Spykman, 1942: 18)

Henceforth, the role of the state in international affairs is always, as Spykman says, to 'facilitate the attainment of power', with the harbouring of any contrary opinions only resulting in eventual disappointment. Accordingly, the moral accompaniment to power ambitions is delivered explicitly and implicitly through communications activities like public diplomacy, which includes, but is not limited to, international broadcasting, cultural diplomacy, education and knowledge exchange, endorsements of other governments, state visits, gestures of goodwill, media and public relations, and foreign aid and development assistance. However, all of these activities have the potential to become redundant if they are deemed to be unimportant or even detrimental to the power quest. This includes all foreign aid. Indeed, foreign aid's usefulness to the power equation is its association with the philanthropy that forms a key part of the prevailing neoliberal ideology's moral justification of itself. In short, neoliberalism's exploitation is propagated as being acceptable as long as a remedy for the suffering that it induces is also provided in some measure. However, this industry, indeed most supposedly charitable acts under neoliberalism, are motivated not by collective compassion but by ego. In short, many of those engaged in these industries are at least partly motivated by the self-confirmation of virtuosity that such a career brings. Additionally, positive external acknowledgement may also be sought for their actions, and offence may be taken if the person being assisted does not bestow an expected level of gratitude. Alternatively, recognition is sought for charitable acts as part of the formation of public persona, now most commonly pursued on social media platforms.

Therefore, neoliberalism has conveniently created a multibillion dollar foreign aid and development industry ready to dispense the advocated prescription and provide some outlet for the ego that capitalism prioritises over compassion. In many ways, therefore, foreign aid resembles a global form of the medical illness Munchausen's by Proxy where sickness is induced in a person by a caregiver in order that attention be drawn to themselves. This rather uncomfortable analogy is at the crux of the conceptualisation of foreign aid as public diplomacy that we will returned to later in the chapter.

The writings of the Italian philosopher and political prisoner Antonio Gramsci (1891 - 1937) have been used in many contexts related to the study of power and communications. Gramsci wrote the following on the uses of morality and culture by the powerful in their pursuit of authority:

In my opinion, the most reasonable and concrete thing that can be said about the ethical and cultural state is this: every state is ethical in as much as one of its most important functions is to raise the great mass of the population to a particular cultural and moral level, a level (or type) which corresponds to the needs of the productive forces of development, and hence to the interests of the ruling classes. The school as a positive educative function, and the courts as a repressive and negative educative function, are the most important state 
activities in this sense: but, in reality, a multitude of other so-called private initiatives and activities tend to the same end - initiatives and activities which form the apparatus of the political and cultural hegemony of the ruling classes. (Gramsci, cited in Forgacs, 1988: 234)

Thus, for Gramsci, whatever that 'particular cultural and moral level' ought to be for those within and beyond the powerful state was decided by whatever the forces of production require it to be. To this end, the landscape of foreign aid at a given time can be linked to the requirements of the means of production through its delivery of a cultural or moral authority that befits the priorities of the prevailing world system and manufactures a sense of power by attraction under the ideological guise. To this end, the key to the maintenance of hegemonic power was through what Gramsci called the 'guardians' of any society. Most likely inspired by Plato's The Republic, Gramsci's guardians essentially amounted to intellectuals whose moral leadership is admired by society and who gain credibility and authority through the perception that they act as intermediaries between the powerful and the suppressed. Think: celebrity endorsement of charities. Gramsci concluded that this is a fabrication as the intellectuals seek the maintenance of at least a semblance of the power status quo. Indeed, they would not be conferred as guardians if they sought anything more radical or revolutionary.

This position is articulated well by the American ethicist Reinhold Niebuhr who wrote that,

No society has ever achieved peace without incorporating injustice into its harmony. Those who would eliminate the injustice are therefore always placed at the moral disadvantage of imperilling its peace. [...] This passion for peace need not always be consciously dishonest. Since those who hold special privileges in society are naturally inclined to regard their privileges as their rights and to be unmindful of the effects of inequality upon the underprivileged [...]. (Niebuhr, 1932: 78)

Thus, those who are held to be guardians of a community will not be advocates of any anarchy, false or otherwise. Niebuhr continues:

The moral attitudes of dominant and privileged groups are characterised by universal selfdeception and hypocrisy. The unconscious and conscious identification of their special interests with general interests and universal values, which we have noted in analysing national attitudes, is equally obvious in the attitude of classes. (Niebuhr, 1932: 72)

This argument concerning the association between privileged class interests and supposed 'universal values' helps to explain the educational narrative of foreign aid and development assistance, which preaches that if only the world's poor could become more efficient and learn from the developed nations then they would somehow 'catch up'. However, this is propagated as part of the creation of attraction that the source seeks for itself as part of its soft power ambitions.

The generation of attraction leads to the question of access to, and control of, cultural spaces and fora. In short, whose voices are heard, who is listened to, and who is marginalised, vilified or even absent altogether. The notion of cultural space, and its control, was discussed at length by the French philosopher Henri Lefebvre during the late twentieth century. Lefebvre's (1991) explained how the narratives of cultural space embody future notions of utopia of the prevailing ideology at a given time. These narratives are the result of 'knowledge' that is propagated as objective, but which is framed by the means of production. Lefebvre (1991: 9) wrote that, "[t]his ideology carries no flag, and for those who accept the practice of which [...] it is indistinguishable from knowledge." It is also 
indistinguishable partly because the individual's egotistical desire to believe in their own virtue and the validity of their life choices. This denial or repression is lived at such a level that various subconscious defence mechanisms are engaged so as not to encounter the discomfort brought by the realisation of contradiction. This critical path is also no doubt discouraged by the mass distractions that all ideologies employ to prevent the potential for cognitive dissonance within their advocates.

In terms of foreign aid then, Foucault (1991) discussed the notion of the 'humanitarian mode of power' in which a subversive authority portrays themselves as the provider of solutions to prevalent social issues while simultaneously utilising natural resources and human labour to meet their own ends. Foucault discussed this within the context of the prison system and the notion of rehabilitation. However, the argument can also be used to explain foreign aid narratives. During the colonial period, for example, the notion of 'civilising' the 'uncivilised' to Western cultural standards became the popular moral justification that accompanied economic exploitation, and this has continued in the postcolonial period in practices of foreign aid and development assistance within the 'catch up' mentality. Foucault's work on the dynamics of discourse and power in the representation of social reality also revealed the mechanisms by which a certain order of discourse produces permissible modes of being and thinking while placing other beyond the pale. This creates senses of what is to be revered and what is unattractive. Thus, the argument that foreign aid represents state philanthropy, rather than an essential part of the power accumulation strategy that dominates policy objectives, likely sits so safely within the perimeters of prevailing discourses that the majority of people consider it to be no argument at all.

The great literary figure Oscar Wilde (1900: 2) once said that, "[...] the worst slave-owners were those who were kind to their slaves, and so prevented the horror of the system being realised by those who suffered from it." To this end, therefore, in many ways foreign aid is an unsatisfactory stopgap that prevents its recipients from receiving social justice and perpetuates, even justifies, their exploitation. Some of those engaged in the industry may mean well. Particularly those on the ground performing its functions. However, they are ultimately misguided or self-deceiving because, far from any moral catalyst, foreign aid symbolises much of the alibi that this deeply unfair world system uses to preserve its legitimacy.

\section{Public Diplomacy, Soft Power and Foreign Aid}

Public diplomacy can be defined as the governmental act of attempting to communicate with foreign publics to assist the power ambitions of the source of these communications. These ambitions are always strategic and economic, such is the overlap between the motives, and involve efforts at engineering cognisant or incognisant positive value judgments about the source, and its domestic and international actions and intentions, in the hope that these transfer into social, economic and political gains. Thus, public diplomacy works well when it balances tendencies towards sharing, equality, understanding and connectedness with other humans, while also stimulating the ego which often prevents the enjoyment of a collective compassionate experience to any great extent. This represents public diplomacy's exploitation of human dialectic for its own ends. As such, public diplomacy's engagement with human tendencies towards compassion for others is one of the main reasons for the positivity and sometimes romanticism that can be found in much of its academic literature. However, its stimulation and incentivisation by the powerful for accumulative and conservative ends, much like foreign aid, ultimately results in the industry existing on a fallacy of compassionate authenticity. 
The terms public diplomacy and soft power are frequently found together in academic literature with the rationale for this usually that public diplomacy is concerned with the generation of soft power for the source of the communications. Consequently, an actor cannot 'do' soft power, so to speak, as soft power can only be bestowed upon an actor by another. Furthermore, soft power can be bestowed upon a benign actor who makes little purposeful or proactive attempt to improve their soft power status but simply acts in a way deemed to be attractive. Thus, soft power status can be achieved without engaging in public diplomacy activities. Finally, while it can be acknowledged that public diplomacy normally seeks to make the source more attractive, this is not a precondition. Indeed, public diplomacy activities have been known to present the source as less attractive to some groups as strategic objectives determine. For example, when seeking to deter some economic migrants or refugees from travelling to the source.

Public diplomacy narratives and activities often epitomise the cultural and national identity of their source. To this end, public diplomacy often uses the knowledge capital of the source's domestic public as part of the persona that it attempts to create in the international sphere. Thus, domestic publics can perform an informal ambassadorial role when public diplomacy activities become an international outlet for the skills of that group. This is particularly prominent when public diplomacy concerns foreign aid, development assistance and some forms of cultural diplomacy, which often seek to harness the talents, knowledge and emotions of the public. What is more, public diplomacy often seeks to massage the collective ego of the domestic public by linking to nationalist desires to believe in the positivity of one's own country's role in the international system and one's individual contribution to it. It can also assist with community building at home.

This domestic function of public diplomacy can be overlooked such is the focus of the literature on international communications. However, most governments considered it important that a country has a clear sense of its past, present and future and incentivises propaganda to induce this. To this end, most countries are founded on myths concerning the shared history of all echelons of society. These are propagandas designed to manufacture the obedience of those experiencing a power deficit and may involve the propagation of a glorious past involving the defeat of barbarous enemies who posed existential threats, a tragic past involving gallant defeat to external forces displaying immense brutality, or a past from which history has been reckoned with or learned from and from which the domestic public can now provide assistance to others around the world as befits public diplomacy priorities.

As this author has argued in other publications (see Alexander, 2014a; 2014b and 2015) foreign aid and development assistance fit well within the remit of public diplomacy and soft power because it seeks to improve the attractiveness of the source within the minds of target domestic and international audiences, such is its positive propagation under prevailing ideology. This chapter has already discussed the notion of morality and foreign policy and this has provided a platform from which specific details of the audiences that foreign aid seeks to engage with can now be understood. This section will now discuss four specific audiences in turn. However, the political elite's consistent unwillingness to acknowledge that foreign aid and development assistance are linked to power ambitions results in the following discussion being largely based on critical analysis alone. Indeed, in many years of interviewing politicians, civil servants and even volunteers involved in foreign aid from a variety of countries, this author has only rarely heard an interviewee admit the power motive of the industry.

One example of such a narrative came from Yen Ming-hong, who, when interviewed in 2013, was the Deputy Director for Technical Cooperation at the Taiwan International Cooperation and Development Fund (ICDF). He stated the following about his government's primary concern over the 
health of diplomatic relationships as motive for providing foreign aid. For Yen, Taiwan's foreign aid had previously amounted to an intergovernmental bribe that befitted Taiwan's international priorities at the time.

In the 1960 s the reason why we were involved in international aid was totally a diplomatic concern. As you know, we are no longer a member of the United Nations, and during that time the Taiwan government tried to keep our allied countries in Africa. So what they came up with was to send out a lot of technical missions to stay there and to provide agricultural assistance in the hope that we can have their diplomatic support. In that time, we were not focused on the results of the projects. We did not care about the results. We just wanted the support of the local governments. (Yen, 2013)

Nevertheless, Yen was adamant that Taiwan's contemporary intent was more philanthropic. This was despite a volume of evidence to the contrary (see Alexander, 2014a and 2015).

\section{The Domestic Audience}

Let us begin this sub-section by reviewing transcripts from the leaders' debates in the lead up to the 2017 UK general election. These narratives do much to reveal how political parties in wealthy states present the notion of foreign aid to their domestic publics.

\section{Transcript of ITV Leaders Debate $18^{\text {th }}$ May 2017}

Paul Nuttall (PN) (Leader of UK Independence Party): [...] We also would put $f 1.4$ billion a year into social care. And how would we pay for this? Well we would take that money directly from a foreign aid budget that is costing us around $f 13$ billion every single year. We would cut that back to $0.2 \%$ of GDP, which is exactly the same as it was in the United States under Barack Obama.

--- (later in the debate) ---

$\mathrm{PN}$ : We take that money from the foreign aid budget which is costing us $£ 30$ million every single day [...]

Leanne Wood (LW) (Leader of Plaid Cymru): Taking it away from refugees then, yeah?

PN: [...] Hang on, hang on. If we reduce foreign aid to $0.2 \%$ that is, as I said earlier, the same as the United States under Obama, the point is [...]

LW: You're stopping refugees coming here, preventing them.

PN: [...] this is about low hanging fruit, there's no need to put up taxation, we can simply take it from the foreign aid budget [...]

Nicola Sturgeon (Leader of the Scottish National Party): Take it from the poorest people in the world?

PN: [...] supporting British people first. Charity begins at home.

(ITV, 2017)

Transcript of BBC Leaders Debate $31^{\text {st }}$ May 2017 
PN: [...] we would slash the foreign aid budget that is costing the British people $\mathrm{f30}$ million a day.

[Incoherent commotion]

Caroline Lucas (Joint Leader of the Green Party): Shame on you!

(BBC, 2017)

These short transcripts present the political propaganda that foreign aid amounts to a form of state charity. Wood, Sturgeon and Lucas, whose parties all occupy the centre or centre-left ground in UK politics, do not question the philanthropic guise of foreign aid that the more right-wing Nuttall emphasises, and are appalled, genuinely or not, by his apparent lack of compassion. The discussion within these debates then, and one that is replicated in political debates in wealthy countries around the world, surrounds how much international state charity should be provided, not whether foreign aid amounts to a form of philanthropy at all. These narratives form a key part of the public discourse that conceives of foreign aid as an act of kindness on the part of government with the primary topic of debate how generous the government ought to be on the electorate's behalf. This nourishes the notion of a domestic collective ego concerning a country and its citizens making a positive contribution to the planet beyond the consumption of its resources, but which is, in reality, motivated by the manufacture of the consent of the domestic public to be ruled.

\section{The Governments of Recipient States}

The second audience of foreign aid that can be discussed are the governments and powerful people within recipient states. In the postcolonial era, these individuals and institutions have been responsible for ratifying the contracts that the governments of wealthy states and international corporations have made to rent and purchase land for a variety of purposes within these countries. This quality land then becomes unavailable for use by the publics of recipient states, squeezing them either into city slums or onto land that is susceptible to climatic variation and/or not suited to the agriculture that it is then asked to produce. This system produces a ready supply of destitute communities primed for 'saving' by foreign aid and development assistance, while also allowing wealthy governments to propagate their moral responsibility to the world's poor, and providing an international outlet for philanthropic, but ultimately misguided, members of their domestic publics. To this end, the next time an appeal from a charity or aid agency appears on the television stating that someone must walk many kilometres from their home to find fresh water, perhaps it should be asked why they live so far from fresh water as this has been the basic premise of all human habitation since the birth of organised society.

Although somewhat limited in its breadth and analysis, Saskia Sassen's (2014) account of the Expulsions of people from land that their families have farmed for generations is a powerful argument about the responsibility for the plight of the world's poor ultimately lying with the rich. Sassen also notes that the twenty-first century has seen an intensification of land acquisition with two significant factors being the main contributors to this. The first is that the rise in food prices has made land an even more desirable investment by international buyers, even for speculative reasons; and the second is the growing demand for industrial crops, notably palm for biofuels, and for food crops, the latter particularly coming from the rapidly developing states of East Asia and the Middle East. The intensive industrialisation of these countries has resulted in additional demands for the products that tend to follow economic growth, with greater meat consumption one area of note. 
What Sassen does not discuss, however, is the process by which the governments of wealthy states and international corporations engineer elections around the world in an attempt at ensuring that the candidates who will provide a preferential treatment of sorts are elected to office. To this end, elections in countries where a significant percentage of land is used for export purposes tend to be swamped with clandestine foreign monies, which by and large control the menu of political choice for the voters. Indeed, even moderately socialist or protectionist groups struggle to start a campaign such is their lack of access to the capital needed to compete in a national election resulting in some turning to violence. This is before consideration is given to the communications professionals who join the teams of preferred candidates to structure the delivery of campaign messages, and researchers who 'muckrake' candidates less favourable to the priorities of international interests, attempting to find any kind of underhand dealing or personal demon. As such, foreign aid in this context is used as an attractive political incentive committed by wealthy states and international corporations to their preferred candidates in recipient states as part of an exchange package that essentially limits the role of the government of poorer states to the welfare of its citizens and largely thwarts any movement towards them achieving social justice within the international system. The governments of these states, and those close to power, thus form one of the key audiences of foreign aid under soft power analysis.

\section{Other International Audiences}

This subsection is formed of a variety of groups and clusters who may have contact with, or become aware of, a government's contribution to the foreign aid industries and who may then make positive value judgments about that contribution and its source. It includes international political, economic and societal groups that a source government conceives of and wants to appeal to as part of their broader strategic international ambitions. The most important of these is the United Nations as this is the primary fora for the debate of global governmental legislation and the international platform for the articulation of the prevailing values of the world system and the policies and positions that follow from them. Other international political groups that source governments regularly attempt to attract include the World Health Organisation, the International Monetary Fund, the World Bank, the European Union, and a variety of regional military alliances.

At the crux of this process of manufacturing attractiveness through foreign aid is a desire to demonstrate conformity with perceived international norms of responsible or dutiful behaviour as have been determined to befit the power status of the source. This process does not necessarily exist on a platform of morality but moral obligation may form part of the propaganda here. Perhaps the most prominent articulation of this ambition comes from separatist regional governments of wealthy states, who, in a bid to demonstrate congruence with prevailing values and consensus on global issues, engage in small amounts of foreign aid as part of what is known as 'protodiplomacy'. By engaging in protodiplomacy these regional governments are implicitly confirming that in the event of their independence from the parent state they would become consistent, regular and reliable members of the so-called international community as their power status would determine. A strong recent example of this has been the Scottish government, which has used foreign aid and development assistance as part of its pro-independence international communications strategy and charm offensive towards major international governmental organisations (see Alexander, 2014b). However, this is a regular activity of all state governments engaged in aid provision as they all articulate their contribution to the industry as part of their political communications towards a host of international audiences beyond the immediate recipients of foreign aid. Indeed, some governments may have reservations about the manner in which aid operates, concerns over 
corruption for example, but will nevertheless continue to engage in the practice in some form as it assists their power ambitions and prevents any negative attention being drawn to themselves lest they be labelled as some kind of foreign aid 'scrooge' by those they seek to influence.

\section{Recipients of Aid and Assistance}

The final audience that requires discussion are those in receipt of an aid package or development programme. Often the receipt of aid or assistance is recognition of some form of capital or usefulness within the priorities of the world system. Beyond this, those facing a nadir of destitution, with seemingly minimal capital, may become recipients because of the so-called 'CNN effect', where the international mainstream news media shine a light on suffering, and, if certain criteria are met, successfully pressurise governments to act (see Robinson, 2002). Linking more to the domestic audience within donor states, this may also present as a form of so-called 'poverty porn', wherein media viewers watch images of suffering as a form of fetish that they subconsciously do not want to see eradicated for it excites them, makes them feel good about themselves or presents them with a guilt narrative that can be conveniently alleviated by charity donation or endorsement of government programmes (see Zizek, 2009). The notions of jouissance and schadenfreude are noteworthy here. Finally, the foreign aid industries require a regular supply of 'success' stories as part of their propaganda that it can make a positive impact on reducing global poverty and capacity building.

\section{Conclusion}

Foreign aid and development assistance are very motivated by the source's power imperative. To this end, these industries ought to be thought of as public diplomacy outputs aimed at the generation of power for the source government in the form of attractiveness rather than power as a result of coercion or persuasion. Foreign aid's lack of regular inclusion within the portfolio of ministers assigned to public diplomacy is synonymous with the fictional demarcation of government departments and a likely attempt by government to prevent the growth of a sense of hypocrisy within their own publics over the international role of those who govern them. This is primarily because public diplomacy tends to be thought of as a communications arm of regular state foreign policy rather than any form of philanthropy. As such, while ministries of foreign affairs are concerned with the consolidation or accumulation of the power status of the source, departments of international development operate separately under the pretence of being motivated by power dispersal. They are not, however, and this demarcation represents part of the Orwellian misconstruction of government.

To conclude then, the evidence presented here strongly suggests that foreign aid is conducted for purposes beyond that of philanthropy despite much of its propaganda narrative indicating philanthropic intentions. One of the most significant factors behind this is because the modern corporate state is increasingly run like a business that is power and capital hungry. To this end, governments employ spin doctors, undertake branding initiatives, perform 'reputation management' and are increasingly subservient to corporate industry rather than the people to which they remain accountable (at least within democracies). Why then should departments of international development be any less 'spun', so to speak? What is more, calls for transparency mean the publication of accounts, much like a public limited company, and subsequent scrutiny and 
justification of expenditure by the domestic public and media. Therefore, it follows that the funding of foreign aid must be in line with the economic and political interests of the source, if the government is to avoid accusations of financial mismanagement or squandering of public funds. Indeed, public diplomacy has had a long and arduous battle with government finance because its results are essentially unquantifiable such is the solipsistic nature of its activities. Thus, while outright plunder cannot occur as it did in colonial times, the ideologically constructed 'benefit' that foreign aid has for any recipient remains utterly subordinate to the source's self-interests.

\section{Bibliography}

Alexander, C., (2015), "The Communication of International Development Assistance: The Case of the Taiwan International Cooperation and Development Fund (ICDF)", Journal of Global Governance, 21(1).

Alexander, C., (2014a), China and Taiwan in Central America: Engaging Foreign Publics in Diplomacy. New York: Palgrave Macmillan.

Alexander, C., (2014b), "The Public Diplomacy of sub-State Actors: The Case of the Scottish Government with Malawi", Palgrave Journal of Public Diplomacy and Place Branding, 10(1).

BBC, (2017), 2017 UK General Election Political Leaders Debate: $31^{\text {st }}$ May 2017. Available from World Wide Web: [https://www.youtube.com/watch?v=xmopAnM_exA]. Accessed $18^{\text {th }}$ July 2017

Escobar, A., (1995), Encountering Development: The Making and Unmaking of the Third World. Princeton: Princeton University Press.

Forgacs, D. (ed.) (1988), A Gramsci Reader. London: Lawrence and Wishart

Foucault, M., (1991), Discipline and Punish: The Birth of the Prison. London: Penguin

ITV, (2017), 2017 UK General Election Political Leaders Debate: $18^{\text {th }}$ May 2017. Available from World Wide Web: [https://www.youtube.com/watch?v=wEgi50IP8co]. Accessed $18^{\text {th }}$ July 2017

Lefebvre, H., (1991), The Production of Space. Oxford: Blackwell

Niebuhr, R., (1932), Moral Man and Immoral Society: A Study in Ethics and Politics. New York: Charles Scriber's Sons

Nye, J. (2004), Soft Power: The Means to Success in World Politics. New York: Public Affairs.

Robinson, P., (2002), The CNN Effect: The Myth of News, Foreign Policy and Intervention. London: Routledge

Rousseau, J. J., (1993), The Social Contract and The Discourses. London: David Campbell Publishers

Sassen, S., (2014), Expulsions: Brutality and Complexity in the Global Economy. Cambridge, MA: Harvard University Press

Schopenhauer, A., (1995), On the Basis of Morality. Indianapolis, IN: Hackett Publishing International Spykman, N., (1942), America's Strategy in World Politics: The United States and the Balance of Power. New York: Harcourt, Brace and Company 
Wilde, O., (1900), The Soul of Man Under Socialism. London: Free River Community

Zizek, S., (2009), First as Tragedy, then as Farce. London: Verso 